\title{
COVID-19-Related Sanitary Crisis and Derogations under Article 15 of the Convention
}

\author{
Considerations in Estonia
}

Maris Kuurberg ${ }^{*}$

\begin{abstract}
During the COVID-19 pandemic, Estonia was one of the states that decided to inform the Secretary General of the Council of Europe of the health-related emergency situation in Estonia and noted, with reference to Article 15 of the European Convention on Human Rights, that some emergency measures may involve a derogation from certain obligations under the Convention. The Government's considerations proceeded from the unprecedented scale of the sanitary crisis and the scope of extraordinary measures taken to tackle it. Importance was attached to the fact that the Court has never before assessed health-related exceptions allowed in some of the articles of the Convention in a situation which affects the whole nation - not to mention the articles of the Convention which do not set out any exceptions at all. Article 15 of the Convention, on the other hand, is designed to be applicable in public emergency situations threatening the life of the nation.
\end{abstract}

Keywords: human rights, emergency situation, COVID-19 and sanitary crisis, Article 15 of the European Convention on Human Rights, European Court of Human Rights (the ECtHR), Estonia.

\section{Introduction}

By the time I am writing this article, it is already a fact that a highly contagious coronavirus disease COVID-19 has spread - and is still spreading - all over the world and its case rate has reached enormous proportions. All states still have to tackle different aspects of the crisis, lacking authorized medicine for treatment or vaccinations against COVID-19, fearing, at the same time, that the situation could worsen again when the autumn comes. But already on 11 March 2020,

* $\quad$ Maris Kuurberg (mag.iur.) has been the Estonian Government Agent before the European Court of Human Rights since 2008 (the views expressed are solely those of the author). She works in the Ministry of Foreign Affairs. She is also a member of the Bureau of the Council of Europe's Steering Committee for Human Rights, as well as a member of the same steering committee and a member of the Committee of Experts on the System of the European Convention on Human Rights. Since 1999, she has been a member of the Estonian Bar Association but her activity as an Attorney at Law is suspended since she joined the Ministry of Foreign Affairs. 
when the World Health Organization (WHO) assessed that an outbreak of COVID-19, which was first identified in December 2019 in Wuhan, China, had reached such a global spread that it could be characterized as a pandemic, it was obvious that no State will remain untouched. Therefore, the WHO repeated its call to governments to take urgent and aggressive action to stop the spread of the virus. ${ }^{1}$ At that time, the WHO considered Europe the active centre of the pandemic with more reported cases and deaths than the rest of the world combined, apart from China. ${ }^{2}$

European states, in turn, rapidly started to take extraordinary steps to fight the spread of that disease. Relying on the WHO's latest assessment and the increasing number of infected persons in Estonia, late in the evening of $12 \mathrm{March}$ 2020, the Government of Estonia also declared an emergency situation in the administrative territory of Estonia. ${ }^{3}$

Estonia was one of the states that also decided to inform the Secretary General of the Council of Europe of the health-related emergency situation in Estonia and noted, with reference to Article 15 of the European Convention on Human Rights ('the Convention'), that some emergency measures adopted temporarily may involve a derogation from certain obligations under the Convention. ${ }^{4}$

As the question 'derogate or not' was heatedly debated in spring 2020, I was asked to shed light on the reasons why Estonia decided to submit a declaration related to Article 15 of the Convention. Submitting that declaration was dependent on the domestic declaration of the emergency situation in Estonia and on the measures that were taken during the emergency situation. Therefore, first the domestic legal system in special situations, the reason and purpose of the COVID-19-related emergency situation and specific measures taken during the latter should be briefly discussed.

\section{Regulation on Special Situations in Estonia}

The domestic regulations on emergency regimes and powers differ from country to country quite considerably. The Constitution of Estonia distinguishes three special situations: state of war (sõjaseisukord, $\S 128$ ), state of emergency (erakorraline seisukord, §129) and emergency situation (eriolukord, $\S 87$ clause 8). ${ }^{5}$ More detailed regulations are laid down in special laws. The declaration of a state

1 See WHO Director-General's opening remarks at the media briefing on COVID-19 [11 March 2020], www.who.int/dg/speeches/detail/who-director-general-s-opening-remarks-at-the-mediabriefing-on-covid-19---11-march-2020.

2 WHO Twitter account, 13 March 2020, https://twitter.com/WHO/status/ 1238494220807213057.

3 RT III, 13 March 2020, 1. Government Order No. 76. Translation into English: www.riigiteataja.ee/en/eli/517032020002/consolide.

4 Note verbal of Estonia, 20 March 2020, https:/vm.ee/sites/default/files/Estonia_for_UN/ Rasmus/notificationjj9017c-en.pdf.

5 RT I, 15 May 2015, 2. Translation into English: www.riigiteataja.ee/en/eli/521052015001/ consolide. 
of war is regulated in the National Defence Act. ${ }^{6}$ A state of emergency, which is declared in the case of a threat to the Estonian constitutional order, is regulated in the State of Emergency Act. ${ }^{7}$ An emergency situation - which is relevant in the present COVID-19 pandemic situation - is regulated by the Emergency Act. ${ }^{8}$

The Emergency Act, in addition, distinguishes two situations: an emergency (hädaolukord) and an emergency situation (eriolukord). According to $\S 2$ (1) of the Emergency Act, an emergency is an event or a chain of events or an interruption of a vital service which endangers the life or health of many people, causes major property damage, major environmental damage or severe and extensive interference with the continuity of vital services, and resolution of which requires prompt coordinated activities of several authorities or persons involved by them, the application of a command organization different from the usual and the involvement of more persons and means than usual. An emergency itself is not officially declared, but if the situation escalates, the Government is authorized and obliged to declare an emergency situation. According to $\S 19$ (1) of the Emergency Act, the Government may declare an emergency situation for resolving an emergency caused by a natural disaster, catastrophe or spread of a communicable disease if it is not possible to resolve the emergency without implementing the command organization or measures provided for in the same chapter. According to the respective provisions, during an emergency situation, the person in charge - appointed by the Government - and other authorized persons may obligate a natural person to perform emergency situation work, expropriate moveable property, impose the duty to grant use of an immovable property or moveable property, impose prohibitions on stay and other restrictions on the freedom of movement, and restrict the holding of public meetings and events. ${ }^{9}$

\section{Declaration of the COVID-19 Emergency Situation and the Measures Taken Thereafter}

In the morning of 12 March 2020, the Prime Minister, who was later on the same day put in charge of the emergency situation, made a statement before the Estonian Parliament. He admitted that there was an emergency (hädaolukord) and that the situation may change within hours and days. He underlined that the primary and most important task of the Government was to protect the health and well-being of the Estonian people. ${ }^{10}$ These constitutional obligations include the State's positive obligation to take appropriate steps to safeguard the lives of

6 RT I, 13 March 2019, 147. Translation into English: www.riigiteataja.ee/en/eli/502042019010/ consolide.

7 RT I, 06 May 2020, 5. Translation into English: www.riigiteataja.ee/en/eli/512052020002/ consolide.

8 RT I, 17 May 2020, 3. Translation into English: www.riigiteataja.ee/en/eli/516052020003/ consolide.

$9 \S$ 26-33 of the Emergency Act. See footnote no. 8.

10 Statement of Prime Minister Jüri Ratas, 12 March 2020. Translation into English: www.kriis.ee/ en/news/political-statement-prime-minister-juri-ratas-riigikogu-12-march-2020. 
those within their jurisdiction - similar to how the European Court of Human Rights (Court) has interpreted Article 2 (right to life) and Article 8 (right to respect for private life) of the Convention. ${ }^{11}$

In line with the constitutional obligations, the Prime Minister further noted in his statement that, to this end, the Government had set six goals:

1 to prevent the further spread of the virus to Estonia;

2 to prevent the local spread of the virus in Estonia;

3 to ensure the capacity of the healthcare system to control the virus and treat the disease caused by it;

4 to raise people's awareness of how to prevent the spread of the virus and treatment of the disease caused by it;

5 to ensure that the population can cope with the indirect effects of the virus;

6 to ensure the functioning of the Estonian economy as normally as possible. ${ }^{12}$

In the evening of the same day, on 12 March 2020, the Government of Estonia, based on clause 8 of $\S 87$ of the Constitution and relevant provisions in the Emergency Act, for the very first time in its history, declared an emergency situation in the entire administrative territory of the Republic of Estonia to be in force initially until 1 May 2020. ${ }^{13}$ It was noted in the Order of the Government that the emergency caused by the spread of the virus could not be resolved without applying the governance arrangements provided for in the Emergency Act. ${ }^{14}$ After the declaration of the emergency situation, the Government and the Prime Minister started to impose specific restrictions and obligations provided for in the Emergency Act to prevent the spread of the virus.

As Estonia informed the Secretary General of the Council of Europe on 20 March 2020, when the first emergency measures had already been taken and implemented, it is appropriate to reflect upon those measures which led the Government to submit a declaration under Article 15 of the Convention in more detail.

On 13 March 2020, the Government approved the first emergency measures and ordered the suspension of regular studies in all educational institutions and introduce distance learning as of 16 March 2020. Only kindergartens and childcare facilities were left for the local authorities to decide upon. By the same order, all public gatherings, film screenings, night clubs, shows/performances, concerts and conferences and sports and exercise events were prohibited. Visiting

11 See e.g. Öneryildiz v. Turkey [GC], no. 48939/99, 30 November 2004, § 71; Guerra and Others v. Italy [GC], 14967/89, 19 February 1998, § 58.

12 Statement of Prime Minister Jüri Ratas, 12 March 2020. See footnote no. 10.

13 Government Order No. 76. See footnote no. 3.

14 See also the Explanatory Report to the Government Order No. 76. www.valitsus.ee/sites/default/ files/eriolukord/sel_vv2076k.pdf. 
museums and other exhibitions was prohibited. Visits to social welfare institutions, hospitals and penitentiary institutions were prohibited. ${ }^{15}$

On 14 March 2020, special restrictions on movement regarding Estonian islands were introduced - at the request of the local authorities and due to the very rapid spread of the virus. Only people with permanent residence on the islands were allowed to travel to the territories. The people currently on the islands were allowed to return home. Likewise, residents of the islands could not leave their place of residence during the restriction on movement, except for reasons provided for in the order. ${ }^{16}$ On 16 March, it was specified that the inhabitants of the islands whose place of work was located outside the restricted area (i.e. mainland Estonia) were allowed to leave the island. However, they could not return to their place of residence until the end of the restriction period. People whose place of work was on the islands could leave the mainland to go to work but they could not return to their place of residence until restrictions on movement were lifted. ${ }^{17}$

Also, on $14 \mathrm{March}$, additional restrictions were imposed on spending leisure time and it was ordered that all sports halls, sports clubs, gyms, spas, swimming pools, water centres, day centres and children's play rooms remain closed. ${ }^{18}$ On 16 March 2020, casinos and slot machine halls were closed because close contact between people and coming into contact with surfaces was unavoidable in these locations. ${ }^{19}$

On 15 March 2020, the Government imposed a 14-day restriction on the movement of people arriving in Estonia from abroad as of 17 March 2020. Within the first two weeks after arrival in Estonia, the person could leave their home or place of stay only at the request of a medical worker or the police or in case of an emergency that was threatening the person's life or health. ${ }^{20}$ On 17 March 2020, the Government granted the Ministry of the Interior permission to include the

15 RT III, 14 March 2020, 1. Government Order No. 77. Translation into English: www.riigiteataja.ee/en/eli/517032020005/consolide. See also RT III, 03 April 2020, 8. On 3 April 2020, by Prime Minister Order No. 58, due to the increasing number of infected persons and to protect extra vulnerable people in care homes, it was decided that people receiving $24 \mathrm{~h}$ special care service and a general care service were not allowed to leave the territory of the care home until the end of the emergency situation. Translation into English: www.riigiteataja.ee/en/eli/ 504042020001/consolide/.

16 RT III, 14 March 2020, 5. Prime Minister Order No. 30. Translation into English [16 March 2020 redaction]: www.riigiteataja.ee/en/eli/517032020007/consolide.

17 Ibid. See also RT III, 28 April 2020, 4. Prime Minister Order No. 54 of 28 March 2020 by which it was decided to apply additional restrictions on the movement and closure of businesses in the municipalities of Saaremaa and Muhu. This measure was needed due to the fact that the most rapid spread of coronavirus continued to take place on these islands. Translation into English: www.riigiteataja.ee/en/eli/530032020001/consolide.

18 RT III, 14 March 2020, 4. Prime Minister Order No. 29. Translation into English [16 March 2020 redaction]: www.riigiteataja.ee/en/eli/ee/517032020006/consolide.

19 RT III, 16 March 2020, 5. Amendments to Prime Minister Order No. 29. Translation into English: www.riigiteataja.ee/en/eli/517032020006/consolide.

20 RT III, 15 March 2020, 1. Government Order No. 78. Translation into English: www.riigiteataja.ee/en/eli/517032020004/consolide. 
Defence League in helping to control the Estonian national border during the emergency situation. ${ }^{21}$

On 16 March 2020, the Council for Administration of Courts issued its recommendations for the courts during the emergency situation. ${ }^{22}$ It was recommended to handle litigation, where possible, in writing. Also, holding hearings via technical means of communication was promoted. However, if the latter was impossible, it was for the judge to decide whether to hold a hearing based on the circumstances of the particular case or to postpone it.

On 24 March 2020, additional measures were ordered which concerned the people-to-people distance in the public space to prevent the spread of COVID-19. According to the $2+2$ rule, there had to be at least 2 metres distance between people and only up to 2 people were allowed to be together in a public space (except families) as of 25 March 2020. Also, the closure of shopping malls (with listed exceptions) and additional entertainment was enforced as of 27 March $2020 .^{23}$

It could be seen from the above-mentioned examples that the Government had taken various restrictive measures which clearly had an impact on everyone in Estonia, regardless of their personal situation or state of health, by 20 March 2020. Although these measures were in accordance with the Estonian Constitution, as well as necessary and proportionate to protect the life and health of people in the context of the COVID-19 pandemic, the situation was far from 'ordinary' or 'normal'. It was also clear that if the number of infected people were to grow, additional measures could be taken in the following days and weeks. Taking into account the completely unprecedented situation, and that the restrictive measures were applied to everyone, Estonia found it proper to also inform the Secretary General of the Council of Europe of the situation that corresponded to a 'public emergency threatening the life of the nation'.

\section{Existence of a Public Emergency Threatening the Life of the Nation}

Article 15 (1) of the Convention lays down that in time of war or other public emergency threatening the life of the nation, any High Contracting Party may take measures derogating from its obligations under this Convention to the extent strictly required by the exigencies of the situation, provided that such measures are not inconsistent with its other obligations under international law.

21 RT III, 17 March 2020, 5. Government Order No. 79. www.riigiteataja.ee/en/eli/518032020001/ consolide.

22 Recommendations of the Council for Administration of Courts for organizing the administration of justice during emergency situation. Translation into English: www.kohus.ee/sites/ www.kohus.ee/files/elfinder/KHN\%20recommendations.docx.pdf.

23 RT III, 24 March 2020, 6. Prime Minister Order No. 45. Translation into English: www.riigiteataja.ee/en/eli/525032020001/consolide. See also RT III, 03 April 2020, 7. Amendments to Prime Minister Order No. 46. To comply with the $2+2$ rule, it was ordered that a store or service venue must calculate the number of customers that can fit in the sales hall at one time. The restriction took effect on 4 April 2020. Translation into English: www.riigiteataja.ee/en/eli/504042020002/consolide. 
Article 15 (2) lists the provisions of the Convention, which could not be derogated from, and Article 15 (3) sets forth the notification obligation.

By now, numerous articles have been published and symposiums held where views pro and contra making a derogation under Article 15 of the Convention have been expressed. However, it could be said that there has been no dispute that the COVID-19 pandemic corresponded to the situation foreseen in Article 15 of the Convention. Already in Lawless v. Ireland (3), ${ }^{24}$ the Court observed, in the general context of Article 15 of the Convention, that the natural and customary meaning of the words "other public emergency threatening the life of the nation" was sufficiently clear: "an exceptional situation of crisis or emergency which affects the whole population and constitutes a threat to the organised life of the community of which the State is composed". The Court has further summarized that the emergency should be actual or imminent; a crisis which concerns only a particular region of the State can also amount to a public emergency threatening the life of the nation; ${ }^{25}$ and the crisis or danger should be exceptional in that the normal measures or restrictions permitted by the Convention for the maintenance of public safety, health and order are plainly inadequate. ${ }^{26,27}$

Although Article 15 has never before been used in a health-related crisis, there is no doubt that a sanitary crisis which involves the entire country (and beyond) could also threaten the life of the nation. In the present case, the threat was actual and imminent as there was no cure against the rapidly spreading COVID-19 and states had to take extraordinary cumulative measures to tackle the situation. In the Memorandum [for the attention of all permanent representations] of the Council of Europe Directorate of Legal Advice and Public International Law of 16 March 2020, ${ }^{28}$ it was noted that "[d]ue to the alarming levels of spread and severity of the COVID-19 disease, it would appear justified to speak of public emergency threatening the life of a nation". In April 2020, the Council of Europe repeated this understanding in its toolkit, which was designed for governments dealing with the present unprecedented and massive scale sanitary crisis. ${ }^{29}$

It is recognised at the outset that governments are facing formidable challenges in seeking to protect their populations from the threat of COVID-19. It is also understood that the regular functioning of society

24 Lawless v. Ireland (3), no. 332/57, 1 July 1961 § 28 (law part) of the judgment.

25 See, for instance, derogations in respect of Northern Ireland in Ireland v. the United Kingdom, 5310/71, 18 January 1978, § 205, and in respect of South-East Turkey in Aksoy v. Turkey, 21987/93, 18 December 1996, § 70.

26 Denmark, Norway, Sweden and the Netherlands v. Greece (the 'Greek case'), 3321/6 and others, 5 November 1969, Commission report, § 153.

27 'Guide on Article 15’, p. 6, Paras. 8-9, www.echr.coe.int/Documents/Guide_Art_15_ENG.pdf. See also factsheet 'Derogation in time of emergency', www.echr.coe.int/Documents/ FS_Derogation_ENG.pdf.

28 Not publicly available.

29 "Toolkit for member states on Respecting democracy, rule of law and human rights in the framework of the COVID-19 sanitary crisis", 7 April 2020, https://rm.coe.int/sg-inf-2020-11respecting-democracy-rule-of-law-and-human-rights-in-th/16809e1f40. 
cannot be maintained, particularly in the light of the main protective measure required to combat the virus, namely confinement. It is moreover accepted that the measures undertaken would inevitably encroach on rights and freedoms which were an integral and necessary part of a democratic society governed by the rule of law. ${ }^{30}$

The aim of this article is to reflect the considerations that were taken into account at the time the Secretary General of the Council of Europe was informed on 20 March 2020 but it is impossible to disregard completely the subsequent developments and assessments. Therefore, it is appropriate to refer that in several articles the same view has also been expressed by scholars. For example, it has been noted that "the coronavirus pandemic is possibly the closest we have ever seen of a phenomenon that can objectively be categorised as necessitating exceptional measures" and that "this is the closest we shall get to an "ideal state of emergency' - the very thing it [Article 15] was designed for". ${ }^{31}$ Another author who has advocated for 'no derogations', at the same time, has also not doubted that "the COVID-19 pandemic will clearly fall within the definition of emergency". ${ }^{32}$ In a more neutral article regarding the question of derogations it has been noted, with reference to the Court's case law, that

there can be no doubt that the threat posed by COVID-19 is, depending upon the country concerned, either actual or imminent, is one involving the whole nation and is one affecting the continuance of organised life in it. ${ }^{33}$

However, regarding the question of whether exceptions permitted by the Convention for the maintenance of public safety, health and order in 'normal times' would have been sufficient or inadequate, the views diverge. Estonia was of the opinion that as the established case law of the Strasbourg Court had never dealt with a comparable situation and did not, therefore, give sufficient guidance, reliance on Article 15 would be appropriate.

30 Ibid., p. 2.

31 A. Greene, 'States should declare a State of Emergency using Article 15 ECHR to confront the Coronavirus Pandemic', Strasbourg Observers, 1 April 2020, https://strasbourgobservers.com/ 2020/04/01/states-should-declare-a-state-of-emergency-using-article-15-echr-to-confront-thecoronavirus-pandemic/.

32 K. Dzehtsiarou, 'COVID-19 and the European Convention on Human Rights', Strasbourg Observers, 27 March 2020, https://strasbourgobservers.com/2020/03/27/covid-19-and-theeuropean-convention-on-human-rights/.

33 J. McBride, 'An Analysis of Covid-19 Responses and ECHR Requirements', ECHR Blog, 27 March 2020, http://echrblog.blogspot.com/2020/03/an-analysis-of-covid-19-responses-and.html. J. McBride referred to A. and Others v. United Kingdom [GC], no. 3455/05, 19 February 2009. 


\section{Exceptionality of the Crisis and Insufficiency of Guidance in the Established Case Law}

Estonia informed the Council of Europe that some of the extraordinary measures taken domestically, reported above, may involve a derogation from certain obligations. Estonia referred in its declaration to Articles 5, 6, 8 and 11 of the Convention, Articles 1 and 2 of the Protocol to the Convention, and Article 2 of Protocol No. 4 to the Convention. ${ }^{34}$ In listing the provisions, the Government decided to refer both to the articles which include exception clauses and allow restrictions on health grounds and those which do not foresee any such exceptions. As noted, the decision was based on the Court's case law, which did not give much guidance on whether health-related restrictions, which have been allowed in individually assessed cases, would be valid in a situation affecting the life of a nation as a whole; that is, in a situation where generalized measures are applied to every person, regardless of their personal situation. It is not for the Government to solve hypothetical future cases but the text of the Convention and the existing case law of the Court clearly illustrate the considerations behind the decision to make a declaration on derogation.

\subsection{Articles of the Convention without Health-Related Exception Clauses}

First, it should be underlined that several relevant articles of the Convention do not set out health-related exceptions. Estonia referred in its declaration to Articles 1 and 2 of the Protocol to the Convention and to Article 6 of the Convention. Although Article 1 of the Protocol to the Convention, which protects the right to property, sets out possible exceptions and restrictions on the grounds of public or general interests, health-related grounds are not specified, and there is no comparable case law either. In the present situation, although the Government has not expropriated any property, the restrictions on movement and social behaviour (the requirement of social distancing) as well as temporary closures of different establishments, both public and private, clearly affected the activities and businesses in question indirectly. The restrictions were aimed the protection of life and health; however, taking into account their wide scale and general application, when evaluating these measures, the overall emergency situation should be taken into account. Notifications under Article 15 render this possible.

Article 2 of the Protocol to the Convention, which lays down the right to education, does not mention any exceptions. In Estonia, all educational institutions were closed and switched to distance learning. The transition to electronic means was taken to protect the life and health of both children and teachers and other school staff, who often belong to the categories of most vulnerable persons (e.g. due to age). Although the transition of basic schools, upper secondary schools, vocational educational institutions, institutions of professional higher education and universities to electronic learning was relatively easy in Estonia - as the respective electronic environment already 
existed - it was nevertheless unprecedented and both families and teachers faced many challenges. If any complaints are assessed in that respect, regardless of the lack of exceptions in the text of Article 2 of the Protocol, the Court should be able to take into account that the measures were taken and implemented in the emergency situation.

The text of Article 6 (1) of the Convention - right to a fair trial - does not include any exceptions. However, the pandemic could in fact affect the possibility to hold oral hearings as well as have an impact on the length of proceedings. The Strasbourg Court also had to re-organize its work and deadlines were prolonged. ${ }^{35}$ Estonia mentioned this article in its declaration due to the recommendations of the Council for Administration of Courts, referred to above, where it was recommended, where possible, to handle litigation in writing. ${ }^{36}$ Even though the administration of justice continued in Estonia and the courts were not closed nor did they stop working, nevertheless, at the beginning of March 2020 it seemed likely that some voluminous criminal cases or other cases where holding oral hearings was required could be postponed, and the overall length of those proceedings could be extended. ${ }^{37}$ It is clear that the possible further length of these proceedings is not attributable to the courts nor to the State that had to protect the life and health of all participants in proceedings and the court personnel. However, the Court - if it were to adjudicate any respective complaints in the future - should also be able to proceed from the fact that the respective procedural decisions were taken in the emergency situation. Again, applying Article 15 enables the State to rely on these considerations.

Estonia also took into account that, like the domestic courts that proceeding from the principle of subsidiarity - should assess all complaints first and will take into account that the measures were taken in the emergency situation, the Strasbourg Court should also be able to proceed from the same point of departure. Submitting the declaration was therefore necessary because in the absence of an official and public notice of derogation, Article 15 does not apply to measures taken by the respondent State. ${ }^{38}$

It has been argued that the Court might take into account the general situation, as it has done, for example, in assessing the fiscal austerity measures [cutting wages, pensions etc.] imposed by Greece in a situation of economic crisis. ${ }^{39}$ However, in the light of Article 15 of the Convention, which is designed

35 See the press-releases of the Court of 16 March 2020, 27 March 2020 and 9 April 2020, http:// hudoc.echr.coe.int/eng-press?i=003-6666795-8866184; http://hudoc.echr.coe.int/eng-press? $\mathrm{i}=003-6670996-8872788$; and http://hudoc.echr.coe.int/eng-press?i=003-6677746-8882977.

36 Recommendations of the Council for Administration of Courts for organizing the administration of justice during emergency situation. See footnote no. 22.

37 See retrospective views of the Chief Justice of the Supreme Court, annual speech before the Riigikogu (Estonian Parliament), 3 June 2020, www.riigikohus.ee/sites/default/files/elfinder/ \%C3\%B5igusalased\%20materjalid/RK\%20esimehe\%20\%C3\%BClevaade\%20Riigikogus \%20\%202018/Riigikohtu\%20esimehe\%20\%C3\%BClevaade\%20kohtukorralduse\%2C \%20\%C3\%B5igusem\%C3\%B5istmise\%20ja\%20seaduste\%20\%C3\%BChetaolisuse \%20kohaldamise\%20kohta.pdf.

38 Cyprus v. Turkey, no. 8007/77, Commission report of 4 October 1983, $\S \S 66-68$.

39 Koufaki and Adely v. Greece, 57665/12 and others, dec. of 7 May 2013. See also McBride, 2020. 
exactly for emergency situations involving the whole country and population, and should be used accordingly, this expectation remains hypothetical. ${ }^{40}$ But even if the Court finally takes the pandemic into account as background information when assessing complaints related to measures taken to combat the spread of COVID-19, that would not lessen the value of specific declarations under Article 15 of the Convention, which were aimed at determining the emergency measures more clearly and transparently, and highlighting that these measures were truly exceptional and temporary.

\subsection{The Remaining Question on the Scope of the Allowed Exceptions and Restrictions}

As noted above, Estonia decided to also refer in its declaration to those articles of the Convention that allow health-related exceptions - Articles 5, 8, 11 and Article 2 of Protocol No. 4. At the outset it should be underlined that the declaration on derogation did not mean that Estonia derogates from all the provisions reflected, but that it may not be able to fulfil all obligations. Estonia referred to these provisions due to the insufficient guidance of the established case law of the Court as it does not cover situations even comparable to the present sanitary crisis and measures taken to tackle the COVID-19 pandemic. Health-related restrictions accepted by the Court have related to specific situations of those persons, and are not comparable to a situation where the whole population is affected by broad strict measures. Some case-law examples, provided next, might help understand how unhelpful the Court's settled case law was in assessing the validity of exceptions, which were designed to be applied in 'normal' circumstances.

The most perceptible limitation, imposed by the state, was the restriction of movement. There was no doubt that Article 2 of Protocol No. 4 is affected. However, as there is just a fine line between deprivation of liberty and restriction of movement, Article 5 of the Convention could also be relevant. Which of these articles is applicable depends on the specific circumstances of a case, as the Court has noted that the difference between deprivation and restriction of liberty is one of degree or intensity, and not one of nature or substance. ${ }^{41}$ It is true that Article 5 (1) (e) also allows the lawful detention of persons for the prevention of the spreading of infectious diseases. However, there is very little case law on that provision. The Court in its case-law Guide has concluded, with reference to Enhorn v. Sweden, ${ }^{42}$ which dealt with a person who was HIV-positive, that the essential criteria when assessing the "lawfulness" of the detention of a person "for the prevention of the spreading of infectious diseases" are: (i) whether the spreading of the infectious disease is dangerous to public health or safety; and (ii) whether detention of the person infected is the last resort in order to prevent the

40 It should also be noted and underlined that Art. 15 is a fully operative provision, e.g. compared to Art. 16 of the Convention, regarding which, the Court, indeed, has found in Perinçek $v$. Switzerland (27510/08, GC 15 October 2010, §§ 118-123) that it reflected an outdated understanding of international law.

41 De Tommaso v. Italy [GC], no. 43395/09, 23 February 2017, § 80; but see also Saar v. Estonia [dec.], 40797/17, 12 November 2019, § 40.

42 Enhorn v. Sweden, no. 56529/00, 25 January 2005, § 4. 
spreading of the disease, because less severe measures have been considered and found to be insufficient to safeguard the public interest. When these criteria are no longer fulfilled, the basis for the deprivation of liberty ceases to exist. ${ }^{43}$ In Enhorn, the Court found a violation of Article 5, as less intrusive measures than detention were not considered.

It is difficult to predict the Court's approach regarding the strict movement restrictions and obligation to stay in quarantine during the COVID-19 pandemic. If some measures are considered to be 'detention', it would be quite far-reaching to expect that exceptions allowed in Article $5 \S 1$ (e) also apply to generally imposed measures. Nothing prevents the Court from taking such a position but in that case the established case law will be significantly developed - which is something a State itself cannot predict. But even if only Article 2 of Protocol No. 4 , which allows health-related restrictions, is considered to be applicable, no comparable case law exists. The Court has accepted small-scale restrictions on movement, but again, can any State be confident that the allowed restrictions are suitable in the present lockdown situations, for example, in the circumstances where the local municipalities on the Estonian islands were isolated? In Landvreugd $v$. the Netherlands ${ }^{44}$ and Olivieira v. the Netherlands ${ }^{45}$ the Court accepted that the applicants were not allowed to enter a particular area for 14 days, as the area had been designated an emergency area due to a drug problem. The applicants themselves were also drug-users and their entrance to the area was prohibited because there was a fear that they would again commit acts disturbing public order. Therefore, the movement restrictions were related to the applicants' previous behaviour. These rare examples are not helpful in a situation where an entire island is locked up.

Article 8 of the Convention, which sets out the right to respect private and family life, also allows exceptions. In Estonia, the main aspect related to that article concerned various visiting rights. ${ }^{46}$ However, there have only been rare cases related to quarantine. In Kuimov v. Russia ${ }^{47}$ the authorities denied the applicant access to his child when she was in hospital and while she was in foster care. Access in the foster home was prohibited due to the 2-month influenza quarantine. In that case the Court found no violation of Article 8 as the period was not too long and also as the applicant could see his child through the glass window on a weekly basis. However, in A.T. v. Estonia ${ }^{48}$ a violation of Article 8 was found in a case where the applicant (a prisoner) visited his seriously ill new-born daughter in the hospital but allegedly was prevented from touching his child. These rare cases, and the latter one did not even concern quarantine, are not easily comparable to a situation where all visits to hospitals, social welfare

46 Art. 8 could also be relevant from other aspects, like compulsory testing and treating or vaccinating. Also significant data protection questions may raise.

47 Kuimov v. Russia, no. 32147/04, 8 January 2009, §§ 103-104.

48 A.T. v. Estonia, no. 23183/15, 13 November 2018, §§ 77-91. 
institutions and prisons were prohibited to everyone, without exceptions or weighing any specific personal circumstances.

Concerning public gatherings, Article 11 (2) of the Convention also accepts restrictions for the protection of health. The same question remains - are general, large-scale prohibitions that affect the whole nation covered by the exceptions meant to be applicable in normal circumstances? The Court has taken into account the health of hunger-strikers and the overall deterioration of sanitary conditions when it accepted that it was justified that France prohibited a long-term (over 2 months) gathering of immigrants in an occupied church and ordered their evacuation. ${ }^{49}$ However, this is hardly a comparable situation. Although it is quite obvious that massive gatherings would be a serious health risk in the COVID-19 situation, and the restrictions should be allowed, as there is no comparable established case law; relying on further exceptions under Article 15 seemed reasonable.

\section{Appropriateness of the Declaration under Article 15 of the Convention}

Exactly for the reason that extensive general restrictions may not fit well under the exceptions allowed in normal circumstances, Article 15 is designed for situations where the whole population is under threat. The decision was taken to submit a declaration under Article 15 of the Convention, listing all the measures taken and all the articles possibly affected. The purpose was to send a signal of transparency and to underline that the extraordinary measures are temporary in nature. The notification was seen to strengthen international human rights by providing the necessary legal and public clarity because

Article 15 is more than just a derogation clause. Its purpose is to protect the essence of the Convention during the time of a derogation and to make sure that the Convention will be fully applied again after the emergency has ceased to exist. Its object is to guarantee the continuing existence of the democratic rule of law. ${ }^{50}$

In subsequent European debates even stronger terms have been used. It has been argued that

the argument that everything can and should be accommodated though the proportionality test reduces Article 15 to a dead letter and, in so doing, eradicates its quarantining effect and potentially increases the possibility of exceptional powers becoming normalised..$^{51}$

50 C. Flinterman, 'Derogation from the Rights and Freedoms in case of a Public Emergency', in F. van Dijk et al. (Eds.), Theory and Practice of the European Convention on Human Rights, Fourth Edition, Antwerpen-Oxford, Intersentia, 2006, p. 1055.

51 Greene, 2020. 
It also has to be taken into account that a State cannot contemplate making a derogation over too long a period. The Commission in the Greek case ${ }^{52}$ stated that it was for the State concerned to notify the measures in question without any unavoidable delay together with sufficient information concerning them to enable the other High Contracting Parties to appreciate the nature and extent of the derogation which the measures involved. Although there are no set deadlines, in Lawless v. Ireland (no. 3) ${ }^{53}$ the Court found that the notification 12 days after the measures entered into force was sufficient. Estonia informed the Council of Europe of the emergency situation declared on 12 March 2020 and of the measures taken thereafter, on 20 March 2020. ${ }^{54}$ The derogation was consistent with Estonia's other obligations under international law as the Secretary General of the United Nations under the International Covenant on Civil and Political Rights was also properly informed. ${ }^{55}$

The submission of the notification did not mean that Estonia stopped guaranteeing the rights set forth in the Convention in the period from 12 March to 17 May 2020, until which date the emergency situation in Estonia was prolonged. ${ }^{56}$ Neither did the Estonian declaration preclude the right of persons to have recourse to Estonian courts for the protection of their rights nor did it change the relevant obligations of Estonia or give the State the right to interfere with the rights of persons without legal grounds. In the article explaining why Estonia made the derogation, ${ }^{57}$ it was underlined that regardless of whether a State has derogated or not, the Court will first examine whether the measures taken can be justified under the substantive articles of the Convention. It is only if it cannot be so justified that the Court will go on to determine whether the derogation was valid or not. And even if the derogation was valid, in any case the measures taken must have a legal basis and lawful purpose and they have to correspond to the proportionality test. ${ }^{58} \mathrm{Mr}$. Linos-Alexandre Sicilianos, the President of the Court until 17 May 2020, has also underlined that, although he has to refrain from taking a clear stance on derogations, what is most important

See footnote no. 26.

See footnote no. $24, \S 47$.

In Estonia, it is the Ministry of Foreign Affairs that organizes the representation of the Republic of Estonia at the European Court of Human Rights, thus, the respective note was submitted by the Ministry of Foreign Affairs, via the Permanent Representation of Estonia to the Council of Europe in Strasbourg. RT I, 13 March 2019, 199, Foreign Relations Act, § 9 (5) 3). Translation into English: www.riigiteataja.ee/en/eli/525032019008/consolide.

55 https://vm.ee/sites/default/files/Estonia_for_UN/Rasmus/estonian_declaration_iccpr.pdf.

56 RT III, 24 April 2020, 5. Amendment to the Government Order No. 76. Translation into English www.riigiteataja.ee/en/eli/524042020008/consolide. See also Note Verbal on withdrawing the Estonian derogation, 16 May 2020, https://rm.coe.int/16809e6409.

57 M. Kuurberg, 'Välisministeerium: inimõiguste piiramisest teavitamine oli meie kohus', Postimees, 28 March 2020, https://arvamus.postimees.ee/6935909/valisministeerium-inimoigustepiiramisest-teavitamine-oli-meie-kohus.

58 'Guide on Article 5 of the ECHR', p. 5, § 4. See footnote no. 43. Specific reference was made to A. and Others v. the United Kingdom [GC], §161; and Lawless v. Ireland (no. 3), § 15. 
is that the measures taken were strictly necessary, proportionate and temporary. ${ }^{59}$

\section{Conclusion}

Estonia, like many other European states, had to declare an emergency situation to protect the life and health of its people and fight the spread of the viral disease COVID-19. Like several other states, Estonia informed the Secretary General of the Council of Europe of possible derogation of some rights set out in the Convention and its Protocols under Article 15 of the Convention. As the domestic emergency situation affected the whole country and every person, it corresponded to the description of Article 15 of the Convention as interpreted by the Court: the threat was both actual and imminent, it involved the whole nation and it affected the continuance of organized life in it.

Without the guidance of comparable established case law and proceeding from the fact that the final assessment whether the measures taken have violated the Convention or not is the sole prerogative of the Strasbourg Court, Estonia found it to be clearer and more transparent to inform the Council of Europe that the extraordinary measures taken may not comply with some articles of the Convention and its Protocols.

Even if to some extent health-related exceptions are set out in the Convention, the scope and generality of the measures taken to tackle the COVID-19 crisis raised the question of whether the exceptions allowed in normal circumstances cover the extraordinary measures of general application. Furthermore, the Venice Commission in its reflection paper ${ }^{60}$ has pointed out the duality of the issue. It has noted that refraining from making a derogation may convey the message that a crisis may be handled without resorting to exceptional powers; on the other hand, a derogation may give a clear indication that certain exceptional measures are truly exceptional and do not 'make the law'. The Venice Commission in its earlier report has also noted that a de facto state of emergency should be avoided, and emergency rule should be officially declared. ${ }^{61}$ It has even been argued that

draconian measures taken in response to a crisis are no less dangerous simply because they are not expressly labelled as emergency powers or are taken under the assumption that they are compatible with the ordinary

59 Statement of Mr. Linos-Alexandre Sicilianos at the COVID-19 thematic conference in St. Petersburg, Russia, 11 April 2020 www.youtube.com/watch?v=HE8IZSgz8Uw.

60 'Respect for Democracy, Human Rights and the Rule of Law During States of Emergency Reflections', 26 May 2020, § 42, www.venice.coe.int/webforms/documents/?pdf=CDLPI(2020)005rev-e.

61 'Compilation of Venice Commission Opinions and Reports on States of Emergency', 16 April 2020, p. 5. www.venice.coe.int/webforms/documents/?pdf=CDL-PI(2020)003-e. 
requirements of human rights law. If anything, these measures are more dangerous as they are not expressly quarantined to exceptional situations. ${ }^{62}$

By submitting the declaration under Article 15 of the Convention, Estonia sent a signal that it did not consider the pandemic situation and related restrictions as a normality and indicated that the measures it was temporarily taking may involve a derogation from the Convention. It remains to be seen what the approach of the Strasbourg Court will be in the future if it has to adjudicate any COVID-19 pandemic-related applications. What Estonia hopes is that the Government does not have to resort to similar strict restrictions any more in the future and that the whole world will be able to return to normality as soon as possible. 